\title{
The Effect of Corporate Social Responsibility, Family Ownership on Tax Avoidance: The Effect of Audit Quality Moderation
}

\author{
Santi Yopie*, \& Elivia \\ The Faculty of Economics, Universitas Internasional Batam, Indonesia \\ * santi.yopie@uib.ac.id
}

\begin{tabular}{l}
\hline Article Info \\
\hline Received : 2021-05-13 \\
Accepted : 2022-01-18 \\
Published : 2022-01-31 \\
\hline
\end{tabular}

Key words: audit quality; corporate social responsibility; family ownership; tax avoidance

Abstract
Large tax receipts are essential for every country for its growth and
development but it's constrained by the fact that some people are not
willing to pay taxes voluntarily and deliberately avoid tax in various
ways. This research aims to examine the effect of corporate social
responsibility, family ownership and audit quality on tax avoidance.
This research also investigates whether audit quality can affect the
causal relation of family ownership to tax avoidance. This research
was conducted using non-financial firms. Total of sample that have
met all the criteria was 158 companies which was registered on the
Indonesia Stock Exchange (IDX) in the period of 2015-2019. Data
obtained were tested with panel regression. Regression analysis
results reveal that corporate social responsibility and tax avoidance
are positively associated, corporation with high corporate social
responsibility disclosure are less likely to engage in tax avoidance.
Family ownership, on the other hand, affects tax avoidance
negatively which means that family firms engage in more tax
avoidance than non-family firms. Audit quality has a significant
positive effect on tax avoidance but does not affect the relationship
of family ownership to tax avoidance.

\section{INTRODUCTION}

Taxes are a major concern of companies because they affect profitability and become a burden to inhibit company growth. The hope of the state to receive large taxes is hampered by people who are reluctant to pay taxes voluntarily, so that they try to avoid taxes by all means. Efforts in tax avoidance must be carried out with appropriate and strategic managerial actions so as not to affect the welfare of people who depend on the largest source of state income, namely taxes (Mustika, Ananto, \& Handayani, 2018).

Tax avoidance activities invite supervision by the government and the public (Zeng, 2018). Although it does not violate applicable laws and regulations, this action is considered immoral (Bae, 2017). To alleviate potential public concerns of the negative impact of tax aggressiveness and to show the public that the company has met community expectations, companies can carry out corporate social responsibility (Richardson, Taylor, \& Lanis, 2013). Corporate Social Responsibility is defined as behavior by companies that exceeds legal commitment to society and the environment (Low, 2016). Gunawan and Tin (2018), and Karyanto \& Martiana (2020) state that in Indonesia, the development of Corporate Social Responsibility is very important because Indonesia faces a number of fundamental problems in environmental, social and economic dimensions. High Corporate Social Responsibility adds to the company's credibility so that the company can avoid suspicion from the authorities (Laguir, Staglianò, \& Elbaz, 2015). Muzakki \& Darsono (2015), Amidu, Kwakye, Harvey, \& Yorke (2016), Hidayati \& Fidiana (2017), Wiguna \& Jati (2017), Zeng (2018), Setiawati \& Adi (2020), obtained research results that corporate social responsibility has a negative effect on tax avoidance. Even Fourati, Affes, \& Trigui (2019) indicate that corporate social responsibility has a strong impact on tax avoidance and both are complementary strategies. 
The decision to do tax avoidance is made by the company management. Usually family companies avoid activities that have the potential to embarrass the company's image and family's good name, one of which includes tax avoidance (Ying, Wright, \& Huang, 2016). Chen, Chen, Cheng, \& Shevlin (2010), Putri (2015), Sánchez-Marín, Portillo-Navarro, \& Clavel (2016), and López-González, Martínez-Ferrero, \& García-Meca (2019) found that ownership family has a positive effect on tax avoidance because they want to maintain the good reputation of the family in a social position. But on the other hand, there are also family company owners who use their power to gain benefits for their extended family. This has been proven in previous research (Zulma, 2016), (Subagiastra, Arizona, \& Mahaputra, 2017), (Gaaya, Lakhal, \& Lakhal, 2017), (Prastiwi \& Ratnasari, 2019), (Niandari, Yustrianthe, \& Grediani, 2020).

Tax avoidance can be countered by the results of the external auditor's report. Public trust depends on the level of transparency of reporting. Public accounting firms that are included in The Big Four are trusted and competent in terms of audit quality to produce reports on the company's actual performance compared to non-Big Four CPA (Purba, 2018). However, the assumptions about audit quality based on the auditors are inconsistent since the Enron case which was audited by CPA Andersen can also occur due to the lack of integrity of the auditors to accept bribes. With the help of auditors, family owners can benefit from a more secure tax evasion in order to avoid reputational damage.

Based on the background presented, this study aims to determine whether corporate social responsibility, family ownership and audit quality affect tax avoidance. The study also examined whether audit quality had a moderating effect on the relationship between family ownership and tax avoidance.

\section{LITERATURE REVIEW}

Based on the KUP Law Number 28 of 2007 Article 1 paragraph 1, it is explained that " Tax means payable mandatory contribution to the state of the individual or entity, which is coercive under the Law, without any direct return and shall be utilized for the need of the state for the greatest prosperity of the people". Taxes paid by business companies come from the company's own profits, namely income tax (PPh), taxes that are paid to individuals or entities on income in a tax year (Farouq, 2018). It becomes a complication between company owners and management, because company income is directly reduced by taxes (Muzakki \& Darsono, 2015). On the one hand, the government seeks to increase the optimization of tax revenue, while the government's efforts conflict with companies as taxpayers because taxes can reduce profits so that companies want minimum tax payments (Turyatini, 2017).

Various strategies that companies can do in tax avoidance are: "tax savings, late payment of taxes, optimizing the permitted tax credit, avoiding tax audits by avoiding overpaying taxes, and avoiding violations of tax regulations" (Sonia \& Suparmun, 2019). With Law No. 36 of 2008 concerning the Fourth Amendment of the Income Tax Law (PPh), 2008 and Government Regulation Number 93 of 2010, 2010 and Regulation of the Minister of Finance Number 76 of 2011 (2011), namely the provision of tax incentives for spending on Corporate Social Responsibility. Following are the incentive programs used are as follows tax exemption, tax deduction / tax allowance / tax relief, and tax credit.

In the form of tax deduction (eliminating company payments related to Corporate Social Responsibility in calculating Taxable Income), so that the Income Tax (PPh) payable is smaller. This is believed to have an effect on tax avoidance treatment (Hidayat, Ompusunggu, \& Suratno, 2016).

The purpose of implementing Corporate Social Responsibility is to create a mutual relationship between the community and developing companies. Companies in Indonesia are expected to carry out Corporate Social Responsibility activities and express them based on ISO 26000 (2010) which underlies the seven core subjects; good corporate governance, human 
rights, human resources, environment, and "right and fair" business practices, consumer issues and community involvement and development (Kurnia, Shaura, Raharjo, \& Resnawaty, 2019). The ethical theory of Corporate Social Responsibility suggests that companies should not take action or carry out an activity only taking economic benefits into account (Amidu et al., 2016). Companies also need to consider the impact for all parties caused by these activities. Most of the taxes are used for government infrastructure and social programs. So that a company that reduces or avoids its taxes (involved in tax avoidance) can provide benefits to shareholders, but can also sacrifice community rights (Sikka, 2010).

\section{Hypothesis Development}

\section{The influence of Corporate Social Responsibility on tax avoidance}

Tax avoidance is classified as a risky activity because it imposes a large negative impact on the company. Dewi \& Noviari (2017) argue that companies with a low Corporate Social Responsibility index are considered not fulfilling social obligations maximally so that they carry out tax strategies that tend to be more aggressively weighed with companies that report more Corporate Social Responsibility. According to research by Lanis \& Richardson (2014), Tjondro, Widuri, \& Katopo (2016), Andhari \& Sukharta (2017), Mao \& Wu (2018), Goerke (2018), Gulzar et al., (2018), López-González et al., (2019), Widyanza (2020), Corporate Social Responsibility has a significant negative effect on tax avoidance.

H1: Corporate Social Responsibility has a significant negative effect on tax avoidance.

\section{The effect of family ownership on tax avoidance}

Family companies care about reputation fees and penalties. In particular, family owners show less tax aggressiveness because they care about "reputation" (Gaaya et al., 2017). Family companies usually avoid risky decisions that can endanger their family's socioeconomic and reputation, because they consider the company as a legacy to be passed on to their offspring (Chrisman \& Patel, 2011). But on the other hand, there are also family company owners who take advantage of their power to gain benefits for their extended family and discriminate against the rights of minority shareholders. Family companies can evade taxes and cover it in various ways, such as other good things, or agree to commit fraud with the authorities. The family as the majority shareholder has a strong position and power to make decisions that benefit them and sacrifice the rights of minority investors (Gaaya et al., 2017).

H2: Family ownership has a positive effect on tax avoidance.

\section{Effect of audit quality on tax avoidance}

Audit quality plays a very important role in determining the level of transparency of a financial report. Companies that were audited by the Big Four CPA had a lower level of fraud compared to companies that were not audited by the Big Four CPA (Hidayati \& Fidiana, 2017). According to Zulma (2016), the financial reporting of non-family companies is more accurate and reliable than the financial statements of family companies. High-quality auditors have less incentive or possibility to participate in corporate tax avoidance activities, because they know that they will suffer dangerous consequences should the tax authorities detect fraud. Their reputation will be damaged and they will lose public trust due to exposed tax avoidance behavior.

H3: Audit quality has a positive effect on tax avoidance.

\section{The effect of audit quality on family ownership relationships on tax avoidance}

Audit quality is recognized as an important management characteristic that tends to moderate the relationship between corporate tax avoidance and family ownership (Wirdaningsih, Sari, \& Rahmawati, 2018). According to Husnin, Nawawi, \& Salin (2016), Suprimarini \& Suprasto (2017), Wirdaningsih et al., 2018) audit quality has a positive effect and moderates the effect of family ownership on tax avoidance. Meanwhile, according to Wijayanti, Wijayanti, \& Samrotun (2016), the effect of audit quality on tax avoidance is not significant.

H4: Audit quality weakens the effect of family ownership on tax avoidance 
Based on the explanation above, a research model can be drawn as follows:

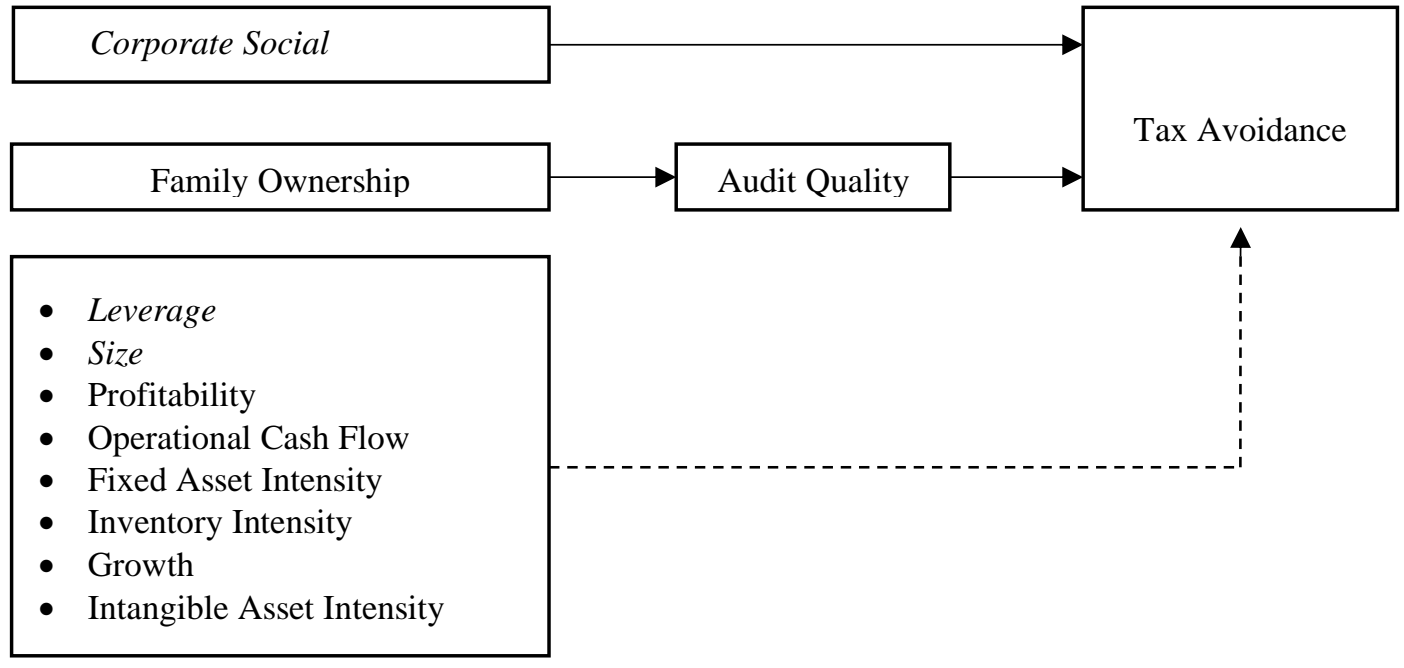

Source: Developed by the author, 2021

\section{METHODS}

\section{Data}

This study uses a quantitative research method. This study uses quantitative data in the form of numbers to analyze the causal relationship between the independent variable and the dependent variable by using secondary data as the object of research. This study uses empirical data from the financial statements of all companies listed on the Indonesia Stock Exchange, by eliminating companies that do not meet certain criteria. The main criterion that must be achieved is that it not a financial company and does not experience a loss in the research period. Only companies that have all the data required for the research will be used.

\section{Operational Definition of Variables and Variable Measurements}

Tax avoidance in this study is measured by the effective tax rate (etr), measured by book tax expense compared to income before book tax. Cash flow effective tax rate (cfetr) is measured by total tax expense compared to operating cash flows. Information from this measurement is obtained from the cash flow statement. Effective tax rate is inversely proportional to tax avoidance behavior. High tax avoidance has a lower effective tax rate (Frank, Lynch, \& Rego, 2009).

Apart from that, as an alternative measurement, the book tax difference (BTD) is also used, which is often used in the taxation literature. The book tax difference is measured by the difference between pre-tax profit and taxable profit compared to the company's total assets. Companies that are involved in higher tax avoidance have a higher book tax difference. The independent variable of this study is corporate social responsibility which is determined by the compliance ratio of the ISO 26,000 core subject index by the company, family ownership is measured by the number of percentages owned by shareholders from the same family and audit quality uses a dummy variable giving a value of 1 if audited by CPA. Big 4 and given a value of 0 otherwise.

To test for the moderating effect of audit quality, we use the value of family ownership times audit quality. To complete the regression research, several control variables were added that could influence tax avoidance behavior. Leverage is the ratio between total long-term debt and total assets. Lanis \& Richardson (2014) found a positive relationship between leverage and tax avoidance.

Size is the scale of the company as measured by the logarithm of total assets. Large companies engage in more aggressive tax avoidance because of the strength they control 
(Richardson et al., 2013). Profitability is measured by ROA (return of assets) with the formula after income tax divided by total assets. Companies with high profitability are likely to do tax avoidance to reduce high tax burdens (Minnick \& Noga, 2010), (Lanis \& Richardson, 2012). Cash flow used for company operations, growth opportunities, namely the ratio of market value to book value of the company. Fixed asset intensity, inventory intensity and intangible asset intensity as measured by the ratio of each variable to total assets (Gaaya et al., (2017), (Gulzar et al., 2018).

\section{RESULTS}

\section{Descriptive Statistics Test Results (ETR)}

On average, the disclosure of Corporate Social Responsibility is $40.56 \%$. The highest disclosure of Corporate Social Responsibility was carried out by PT Unilever Indonesia Tbk amounting to $86.5 \%$ as many as 32 indicators from 37 indices, while the lowest disclosure of only 1 indicator occurred in a number of companies simultaneously. The percentage of family firms is $18.09 \%$ on average, with the highest level of ownership owned by the company PT FKS Multi Agro Tbk at $89.5 \%$. The minimum value of family ownership is 0 , which indicates that the company does not have family shareholders. The companies audited by Big4 auditors were 367 data or equivalent to $46.6 \%$, while 421 other data or $53.4 \%$ were audited by non-big4 auditors. So, concluding that the data in this study is more about the use of non-big 4 external auditors.

\section{Descriptive Statistical Test Results (CFETR)}

Corporate social responsibility is fulfilled as much as $41.22 \%$ with a standard deviation of $17.48 \%$. Family ownership is $16.3 \%$ with a standard deviation of $27.62 \%$. The minimum profitability value of -0.0054 by PT Pioneerindo Gourmet Internasional Tbk in 2015 was due to the amount of current tax expense and deferred tax expense in the current year that exceeded the profit before tax so that the net profit after tax became a loss condition. Operating cash flow here shows that there is no company with minus cash, indicating that all company data manages cash for operating activities quite well, so that the acquisition of cash from operating activities is at least Rp. 2 billion. There are 261 data companies with big4 auditors, and 225 data that are not companies with big4 auditors, only a difference of $7.4 \%$ of the total.

\section{Descriptive Statistics Test Results (BTD)}

On average, the Corporate Social Responsibility is $40.52 \%$ with a standard deviation of $17.51 \%$. Family ownership is $18.16 \%$ with a standard deviation of $28.73 \%$. The average moderation between audit quality and family ownership is $5.79 \%$ with a standard deviation of $17.75 \%$. The book tax difference is $4.29 \%$ with a standard deviation of $8.81 \%$.

Table 1. Effective Tax Rate

\begin{tabular}{|c|c|c|c|}
\hline Variable & Coefficient & Prob. & Result \\
\hline (Constant) & 0.99402 & 0.0000 & \\
\hline Corporate Social Responsibility & 0.035661 & 0.3833 & Insignificant \\
\hline Family Ownership & -0.103602 & 0.0151 & Significant (-) \\
\hline Audit quality & 0.027256 & 0.1987 & Insignificant \\
\hline Family Ownership x audit quality & 0.076953 & 0.2527 & Insignificant \\
\hline Leverage & 0.068143 & 0.3401 & Insignificant \\
\hline Size & -0.022749 & 0.0061 & Significant (-) \\
\hline Profitability & -0.983354 & 0.0000 & Significant (-) \\
\hline Operational Cash Flow & 0.0000 & 0.1093 & Insignificant \\
\hline Fixed Asset Intensity & -0.035712 & 0.4761 & Insignificant \\
\hline Inventory Intensity & -0.110526 & 0.1709 & Insignificant \\
\hline
\end{tabular}


The Effect of Corporate Social Responsibility, Family Ownership on Tax Avoidance: The Effect of Audit Quality Moderation

\begin{tabular}{lrrr} 
Growth & 0.003986 & 0.0101 & Significant (+) \\
Intangible Asset Intensity & -0.016785 & 0.8801 & Insignificant \\
R-Squared & & & 0.112615 \\
Adjusted R-Squared & & & 0.098874 \\
\hline
\end{tabular}

Source: Procesed by the author, 2021.

The test results conclude that from the research model, Corporate Social Responsibility, audit quality does not have a significant effect on the effective tax rate, and the moderating effect of audit quality does not affect the relationship of family ownership to the effective tax rate. Family ownership has a negative effect on the effective tax rate. In other words, high family ownership indicates high tax avoidance. From the collection of control variables, the variable Size, and profitability have a significant negative effect, while growth opportunities have a positive effect on the Effective Tax Rate.

Table 2. Cash Flow Effective Tax Rate

\begin{tabular}{lrrr}
\hline Variable & Coefficient & Prob. & \\
\hline (Constant) & 20.54611 & 0.0414 & \\
Corporate Social & 1.485416 & 0.0216 & Significant (+) \\
Responsibility & -0.303232 & 0.858 & Insignificant \\
Family Ownership & 0.222899 & 0.5901 & Insignificant \\
Audit quality & -0.892231 & 0.5907 & Insignificant \\
Family Ownership x & 1.095542 & 0.3718 & Insignificant \\
audit quality & -0.735105 & 0.0346 & Significant (-) \\
Leverage & -0.2614 & 0.8729 & Insignificant \\
Size & $(0.0000)$ & 0.0214 & Significant (-) \\
Profitability & 0.371458 & 0.6678 & Insignificant \\
Operational Cash Flow & 3.909543 & 0.0903 & Significant (+) \\
Fixed Asset Intensity & 0.00723 & 0.7667 & Insignificant \\
Inventory Intensity & 2.31396 & 0.373 & Insignificant \\
Growth & & & 0.265961 \\
Intangible Asset & & & 0.053167 \\
Intensity & & & \\
R-Squared & & & \\
Adjusted R-Squared & & &
\end{tabular}

With the cash flow effective tax rate, the test results show that corporate social responsibility negatively affects tax avoidance. The meaning of the negative influence is that the more indicators the company fulfills, the smaller the tax aggressive activities. Meanwhile, for family companies and audit quality does not have a significant effect on tax avoidance.

Table 3. Book Tax Difference

\begin{tabular}{|c|c|c|c|}
\hline Variable & Coefficient & Prob. & Result \\
\hline (Constant) & 0.440156 & 0.2106 & \\
\hline $\begin{array}{l}\text { Corporate Social } \\
\text { Responsibility }\end{array}$ & 0.013622 & 0.5915 & Insignificant \\
\hline Family Ownership & -0.0006 & 0.9927 & Insignificant \\
\hline
\end{tabular}




\begin{tabular}{lrrr} 
Audit quality & 0.037427 & 0.0242 & Significant (+) \\
Family Ownership x & -0.017139 & 0.8088 & Insignificant \\
audit quality & 0.108985 & 0.0268 & Significant (+) \\
Leverage & -0.018464 & 0.1331 & Insignificant \\
Size & 0.887522 & 0.0000 & Significant (+) \\
Profitability & $(0.00000)$ & 0.636 & Insignificant \\
Operational Cash Flow & 0.034516 & 0.3534 & Insignificant \\
Fixed Asset Intensity & 0.101481 & 0.1782 & Insignificant \\
Inventory Intensity & 0.000151 & 0.8981 & Insignificant \\
Growth & 0.058834 & 0.6091 & Insignificant \\
Intangible Asset & & & 0.675401 \\
Intensity & & & 0.586874 \\
R-Squared & & & \\
Adjusted R-Squared & & & \\
\hline
\end{tabular}

Source: Procesed by the author, 2021.

From the test results on tax avoidance by measuring the Book Tax Difference, it is found that the audit quality results positively affect tax avoidance with a coefficient value of 0.037427. This result shows that companies with audit quality by the big four tend to be caught doing tax avoidance actions. Meanwhile, the level of Corporate Social Responsibility that is fulfilled and family-type ownership does not have a significant effect on tax avoidance from the measurement of the book tax difference.

\section{DISCUSSION}

\section{Hypothesis 1 Test Results}

The three measurements prove that corporate social responsibility has a significant effect on tax avoidance by measuring the cash flow effective tax rate. The positive coefficient value indicates that companies with high corporate social responsibility tend not to make tax avoidance efforts, but it can only be proven that there is a significant difference in the measurement of the cash flow effective tax rate. So that $\mathrm{H}_{1}$ is accepted if the measurement of the cash flow effective tax rate is used.

\section{Hypothesis 2 Test Results}

The significant test results show that family ownership has an effect on tax avoidance by measuring the effective tax rate. The effect is given as much as -0.103602 on tax avoidance with a probability of 0.0151 , which means that it has a significant negative effect on the effective tax rate because it is below 0.05. The lower the effective tax rate, the higher the level of tax avoidance. The conclusion is that the greater the percentage of family ownership in a company, the greater the possibility that the company is involved in tax avoidance. Conversely, the more diverse the ownership in a company that is not from one family, the lower the level of tax avoidance. Research in line with research by Zulma (2016) Subagiastra, Arizona, and Mahaputra (2017), Gaaya et al. (2017), Ratnasari \& Nuswantara (2020), Niandari, Yustrianthe, $\&$ Grediani (2020) that companies use power as the largest stakeholder in a company to gain profit. The research is in line with the second hypothesis, namely: "family ownership has a positive effect on tax avoidance" so that $\mathrm{H}_{2}$ is accepted."

\section{Hypothesis 3 Test Results}

The test results obtained from the dependent measurement of the effective tax rate and cash flow effective tax rate are not significant, but with a book tax difference, the results show a significance of 0.0242 with a coefficient of 0.037427 that shows that audit quality has a positive 
effect on tax avoidance. The results of this study are in accordance with hypothesis three so that $\mathrm{H}_{3}$ is accepted. Annisa and Kurniasih (2008), Maharani \& Juliarto (2019) support the results of this study that in Luhgiatno's (2008) study, an example of the Enron case has damaged the reputation of CPA Arthur Anderson due to audit failures. Thus, the credibility of external financial reporting is a big consideration by users of external financial information. This has made the B4 CPA more careful in auditing client financial reports. Companies that are audited by the B4 CPA have the risk of getting more difficult to carry out tax aggressiveness. Thus, it means that the B4 CPA is more effective in knowing tax aggressiveness. This is clearly evidenced by the urgency of research on well-known companies conducting tax avoidance audited by CPA B4. Amazon, Apple.Inc, Facebook that do tax evasion are audited by Ernst \& Young, Microsoft and Linkedin audited by Deloitte (Kevin, 2012).

\section{Hypothesis 4 Test Results}

The results of the test on the effect of audit quality on the relationship between family ownership and tax avoidance are not significant so that the fourth hypothesis which says "audit quality weakens the effect of family ownership on tax avoidance" is rejected. Audit quality is one of the most important indicators in corporate governance that can mitigate conflicts of interest among stakeholders in the company. Maharani et al., (2019) stated that this was due to the weak implementation of corporate governance in Indonesia.

\section{CONCLUSIONS AND SUGGESTIONS}

Based on the research results, the corporate social responsibility variable has a negative effect on tax avoidance partially with different measurements. Family ownership and audit quality have a positive effect on tax avoidance by measuring the effective tax rate. Audit quality was found there have no effect on the relationship between family ownership and tax avoidance. These results indicate that companies with high disclosure of corporate social responsibility do not practice aggressive tax avoidance, high family ownership does more tax avoidance, and CPA Big 4 is better able to detect tax avoidance actions taken by companies.

In further research, it can test the effect of management compensation. With that it can be seen whether there is an influence for tax avoidance from the level of compensation to management, corporate social responsibility activities carried out, compensation for management and family ownership. Additionally, it can add control variables such as board size, and the gender diversity of company boards.

\section{REFERENCES}

Amidu, M., Kwakye, T. O., Harvey, S. K., \& Yorke, S. M. (2016). Do firms manage earnings and avoid tax for corporate social responsibility? Journal of Accounting and Taxation, 8(2), 11-27. https://doi.org/10.5897/jat2016.0218

Andhari, P. A. S., \& Sukharta, I. M. (2017). Pengaruh Pengungkapan Corporate Social Responsibility, Profitabilitas, Inventory Intensity, Capital Intensity Dan Leverage Pada Agresivitas Pajak. E-Jurnal Akuntansi, 18(2017), 2115-2142. Available at: https://ojs.unud.ac.id/index.php/Akuntansi/article/view/25794

Annisa, N. A. (2008). Pengaruh Corporate Governance Terhadap Tax Avoidance. 123-136.

Bae, S. H. (2017). The association between corporate tax avoidance and audit efforts: Evidence from Korea. Journal of Applied Business Research, 33(1), 153-172. https://doi.org/10.19030/jabr.v33i1.9887

Chen, S., Chen, X., Cheng, Q., \& Shevlin, T. (2010). Are family firms more tax aggressive than non-family firms? Journal of Financial Economics, 95(1), 41-61. https://doi.org/10.1016/j.jfineco.2009.02.003 
Chrisman, J. J., \& Patel, P. C. (2011). Variations in R\&D Investments of Family and Nonfamily Firms: Behavioral Agency and Myopic Loss Aversion Perspectives. The Academy of Management Journal. https://doi.org/10.5465/amj.2011.0211

Dewi, N. L. P. P., \& Noviari, N. (2017). Pengaruh Ukuran Perusahaan, Leverage, Profitabilitas dan Corporate Social Responsibility terhadap Penghindaran Pajak (Tax Avoidance). EJurnal Akuntansi Universitas Udayana, 21, 830-859. https://doi.org/10.24843/EJA.2017.v21.i02.p01

Farouq, M. (2018). Hukum Pajak di Indonesia: Suatu Pengantar Ilmu Hukum Terapan di Bidang Perpajakan (Pertama). Jakarta: KENCANA.

Fourati, Y. M., Affes, H., \& Trigui, I. (2019). Do Socially Responsible Firms Pay The Right Part of Taxes - Evidences from the Europian Union. Journal of Applied Business and Economics, 21(1), 24-48. https://doi.org/10.33423/jabe.v21i1.655

Frank, M. margaret, Lynch, L. J., \& Rego, S. O. (2009). Tax Reporting Aggressiveness and Its Relation Financial Reporting University of Virginia. Accounting Review, 84(2), 467-496. https://www.jstor.org/stable/27802660

Gaaya, S., Lakhal, N., \& Lakhal, F. (2017). Does family ownership reduce corporate tax avoidance? The moderating effect of audit quality. Managerial Auditing Journal, 32(7), 731-744. https://doi.org/10.1108/MAJ-02-2017-1530

Goerke, L. (2018). Corporate social responsibility and tax avoidance. Journal of Public Economic Theory, 21(2), 310-331. https://doi.org/10.1111/jpet.12341

Gulzar, M. A., Cherian, J., Sial, M. S., Badulescu, A., Thu, P. A., Badulescu, D., \& Khuong, N. V. (2018). Does corporate social responsibility influence corporate tax avoidance of Chinese listed companies? Sustainability (Switzerland), 10(12). https://doi.org/10.3390/su10124549

Gunawan, J., \& Tin, S. (2018). The development of corporate social responsibility in accounting research: evidence from Indonesia. Social Responsibility Journal, 15(5), 671-688. https://doi.org/10.1108/SRJ-03-2018-0076

Hidayat, K., Ompusunggu, A. P., \& Suratno, H. (2016). Pengaruh Corporate Social Responsibility Terhadap Agresivitas Pajak Dengan Insentif Pajak Sebagai Pemoderasi. Jurnal Ilmiah Akuntansi Fakultas Ekonomi, 2(2), 39-58. https://doi.org/10.34204/jiafe.v2i2.543

Hidayati, N., \& Fidiana. (2017). Pengaruh Corporate Governance Social Responsibility dan Good Corporate Governance terhadap Pengindaran Pajak. Jurnal Ilmu dan Riset Akuntansi, 6, 1053-1070. http://jurnalmahasiswa.stiesia.ac.id/index.php/jira/article/view/1005

Husnin, A. I., Nawawi, A., \& Salin, A. S. A. P. (2016). Corporate governance and auditor quality - Malaysian evidence. Asian Review of Accounting, 24(2), 202-227. https://doi.org/10.1108/ARA-11-2013-0072

Karyanto, B., \& Martiana, R. (2020). Peran Akuntan dan Perusahaan Menuju Tujuan Pembangunan Berkelanjutan (Sustainable Development Goals/ SDGs) 2030. Jurnal Studia, $8(1), 109-120$.

Kevin. (2012). Who audits....Apple, Google, Facebook, and Microsoft/LinkedIn? Diambil 1 Februari 2021, dari StockKevin website: http://www.stockkevin.com/2012/09/whoauditsapple-google-facebook-and.html\#.YBqxKugzY2w

Kurnia, A., Shaura, A., Raharjo, S. T., \& Resnawaty, R. (2019). Sustainable Development and CSR. Prosiding Penelitian \& Pengabdian Kepada Masyarakat, 6(3), 231-237. https://doi.org/2581-1126 
The Effect of Corporate Social Responsibility, Family Ownership on Tax Avoidance: The Effect of Audit Quality Moderation

Laguir, I., Staglianò, R., \& Elbaz, J. (2015). Does corporate social responsibility affect corporate tax aggressiveness? Journal of Cleaner Production, 107, 662-675. https://doi.org/10.1016/j.jclepro.2015.05.059

Lanis, R., \& Richardson, G. (2012). Corporate social responsibility and tax aggressiveness: An empirical analysis. Journal of Accounting and Public Policy, 31(1), 86-108. https://doi.org/10.1016/j.jaccpubpol.2011.10.006

Lanis, R., \& Richardson, G. (2014). Is Corporate Social Responsibility Performance Associated with Tax Avoidance? https://doi.org/10.1007/s10551-014-2052-8

López-González, E., Martínez-Ferrero, J., \& García-Meca, E. (2019). Does corporate social responsibility affect tax avoidance: Evidence from family firms. Corporate Social Responsibility and Environmental Management, 26(4), 819-831. https://doi.org/10.1002/csr.1723

Low, M., P. (2016). Corporate Social Responsibility and the Evolution of Internal Corporate Social Responsibility in $21^{\text {st }}$ Century. Asian Journal of Social Sciences and Management studies, 3(1), 56-74.

Luhgiatno. (2008). Analisis Pengaruh Kualitas Audit Studi Pada Perusahaan Yang Melakukan IPO ( Analysis the effect audit quality from earning management). Fokus Ekonomi, 5(2), 1531.

Maharani, W., \& Juliarto, A. (2019). Pengaruh Kepemilikan Keluarga Terhadap Tax Avoidance Dengan Kualitas Audit Sebagai Variabel Moderating. Diponegoro Journal of Accounting, $8(4), 1-10$.

Mao, C., \& Wu, W. (2018). Moderated mediation effects of corporate social responsibility performance on tax avoidance : evidence from China. Asia-Pacific Journal of Accounting \& Economics, OO(00), 1-18. https://doi.org/10.1080/16081625.2019.1546157

Minnick, K., \& Noga, T. (2010). Do corporate governance characteristics influence tax management? Journal of Corporate Finance, 16(5), 703-718.

https://doi.org/10.1016/j.jcorpfin.2010.08.005

Mustika, R., Ananto, R. P., \& Handayani, D. (2018). Analisis Tarif Pajak Efektif di Indonesia. Jurnal Akuntansi, Keuangan dan Bisnis, 11(2), 1-8. Diambil dari http://jurnal.pcr.ac.id

Muzakki, M. R., \& Darsono. (2015). Pengaruh Corporate Social Responsibility Dan Capital Intensity Terhadap Penghindaran Pajak. Jurnal Akademi Akuntansi, 1(1), 1-8. https://doi.org/10.22219/jaa.v1i1.6947

Niandari, N., Yustrianthe, R. H., \& Grediani, E. (2020). Kepemilikan Manajerial dan Praktik Penghindaran Pajak. 2020 Owner (Riset dan Jurnal Akuntansi), 4(2), 459-466. https://doi.org/https://doi.org/10.33395/OWNER.V4I2.250

Peraturan Menteri Keuangan Nomor 76 tahun 2011. , (2011).

Peraturan Pemerintah Nomor 93 Tahun 2010. , (2010).

Prastiwi, D., \& Ratnasari, R. (2019). The Influence of Thin Capitalization and The Executives' Characteristics Toward Tax Avoidance by Manufacturers Registered on ISE in 2011-2015. AKRUAL: Jurnal Akuntansi, 10(2), 119. https://doi.org/10.26740/jaj.v10n2.p119-134

Purba, D. M. (2018). The Influence of Earnings Management, Audit Quality and CEO Duality on Tax Avoidance. The Accounting Journal of Binaniaga, 3(1), 25. https://doi.org/10.33062/ajb.v3i1.175 
Putri, R. K. (2015). Pengaruh Manajemen Keluarga Terhadap Penghindran Pajak. AKRUAL: Jurnal Akuntansi, 7(1), 61. https://doi.org/10.26740/jaj.v7n1.p60-72

Ratnasari, D., \& Nuswantara, D. A. (2020). Pengaruh Kepemilikan Institusional dan Leverage terhadap Penghindaran Pajak (Tax Avoidance). Jurnal Akuntansi AKUNESA, 9(1).

Richardson, G., Taylor, G., \& Lanis, R. (2013). The impact of board of director oversight characteristics on corporate tax aggressiveness: An empirical analysis. Journal of Accounting and Public Policy, 32(3), 68-88. https://doi.org/10.1016/j.jaccpubpol.2013.02.004

Sánchez-Marín, G., Portillo-Navarro, M. J., \& Clavel, J. G. (2016). The influence of family involvement on tax aggressiveness of family firms. Journal of Family Business Management, 6(2), 143-168. https://doi.org/10.1108/JFBM-03-2015-0017

Setiawati, F., \& Adi, P. H. (2020). Pengaruh Corporate Social Responsibility Terhadap Tax Avoidance pada Perusahaan Manfaktur yang Terdaftar pada Bursa Efek Indonesia Tahun 2014-2017. Jurnal Ilmiah Akuntansi dan Keuangan, 9(2), 105-116. https://doi.org/10.32639/jiak.v9i2.451

Sikka, P. (2010). Smoke and mirrors: Corporate social responsibility and tax avoidance. Accounting Forum, 34(3-4), 153-168. https://doi.org/10.1016/j.accfor.2010.05.002

Sonia, S., \& Suparmun, H. (2019). Factors Influencing Tax Avoidance. 73, $238-243$. https://doi.org/10.2991/aicar-18.2019.52

Subagiastra, K., Arizona, I. P. E., \& Mahaputra, I. N. K. A. (2017). Pengaruh Profitabilitas, Kepemilikan Keluarga, dan Good Corporate Governance terhadap Penghindaran Pajak (Studi pada Perusahaan Manufaktur di Bursa Efek Indonesia). Jurnal Ilmiah Akuntansi, 1(2), 167-193. https://doi.org/10.23887/jia.v1i2.9994

Suprimarini, N. P. D., \& Suprasto, B. (2017). Pengaruh Corporate Social Responsibility, Kualitas Audit, dan Kepemilikan Institusional pada Agresivitas Pajak. E-Jurnal Akuntansi Universitas Udayana, 19, 1349-1377.

Tjondro, E., Widuri, R., \& Katopo, J. M. (2016). Kualitas Corporate Social Responsibility dan Penghindaran Pajak dengan Kinerja Laba Sebagai Moderator. Jurnal Akuntansi dan Keuangan, 18(2), 105-118. https://doi.org/10.9744/jak.18.2.105-118

Turyatini, T. (2017). The Analysis of Tax Avoidance Determinant on The Property and Real Estate Companies. Jurnal Dinamika Akuntansi, 9(2), 143-153.

https://doi.org/10.15294/jda.v9i2.10385

Undang Undang KUP Nomor 28 Tahun 2007. (2007).

Undang Undang No 36 Tahun 2008 tentang Perubahan Ke Empat Undang Undang Pajak Penghasilan (PPh). (2008).

Widyanza, P. (2020). Corporate Social Responsibility Disclosure And Good Corporate Governance On Tax Avoidance. 10(8), 622-632. https://doi.org/10.29322/IJSRP.10.08.2020.p10479

Wiguna, I. P. P., \& Jati, I. K. (2017). Pengaruh Corporate Social Responsibility, Preferensi Risiko Eksekutif, dan Capital Intensity pada Penghindaran Pajak. E-Jurnal Akuntansi Universitas Udayana, 21, 418-446.

Wijayanti, A., Wijayanti, A., \& Samrotun, Y. C. (2016). Pengaruh Karakteristik Perusahaan, GCG dan CSR terhadap Penghindaran Pajak. Seminar Nasional IENACO, 712-717.

Wirdaningsih, Sari, R. N., \& Rahmawati, V. (2018). Pengaruh kepemilikan keluarga terhadap penghindaran pajak dengan efektivitas komisaris independen dan kualitas audit sebagai 
The Effect of Corporate Social Responsibility, Family Ownership on Tax Avoidance: The Effect of Audit Quality Moderation

pemoderasi. 15-29. Diambil dari https://ejournal.unri.ac.id/index.php/JA/article/viewFile/6594/5937

Ying, T., Wright, B., \& Huang, W. (2016). Ownership Structure and Tax Aggressiveness of Chinese Listed Companies Article information : International Journal of Accounting \& Information Management.

Zeng, T. (2018). Relationship between corporate social responsibility and tax avoidance: international evidence. Social Responsibility Journal, 15(2), 244-257. https://doi.org/10.1108/SRJ-03-2018-0056

Zulma, G. W. M. (2016). Family Ownership , Management Compensation, And Tax Avoidance : Evidence From Indonesia. The Indonesian Journal of Accounting Research, 19(1), 97-110. 